DOI: https://doi.org/10.24113/ijellh.v8i1.10413

\title{
Are Archetypes Not Enough in Children's Literature? A Case Study of Body Shaming and Stereotypes in Roald Dahl's The Twits And The Witches
}

\author{
Akanksha Bahukhandi \\ Research Scholar \\ Department of English \\ H.N.B.G.U, Srinagar \\ Uttarakhand, India \\ bahukhandi.akanksha@gmail.com
}

\section{Abstract}

Archetypes are easily identifiable in works of fiction regardless of when they were penned and the relevant cultural mileu. This is because archetypes are functional units of the 'collective unconcious' which is common to all. Going by that logic shouldn't the authors of fiction be just fine with exploring various aspects and variations af various archetyes deep seated in the psyche of their readers? If archetypes provide a sound base of ready acceptance by virtue of their familiarity to the entire human race, then what explains the rampant use of strereotypical characters and plots in fiction all across the globe and especially in children's literature? Do the stereotypes encourage prejudices and body shaming? The present paper aims to look into the possible reasons behind the use of stereotypes and caricatures, their effectiveness and their impact on the young readers.

Keywords: Archetypes, Stereotypes, Children's literature, Body Shaming, Prejudices. 


\section{DOI: $\underline{\text { https://doi.org/10.24113/ijellh.v8i1.10413 }}$}

Archetypes form an intergral part of the building blocks that form a story. They are the common ground on which the writers build their imagination and give their readers different yet familiar and appealing works of fiction. Children's literature is a rich repository of stories and novels that rely heavily on the effective use of archetypes and archetypal patterns. According to C.G Jung archetypes can be understood as "identical psychic structures common to all", which form "the archaic heritage of humanity" (qtd. in Stevens 47). Jung considered them as "innate neuropsychic centres possessing the capacity to initiate, control, and mediate the common behavioural characteristics and typical experiences of all human beings " (Stevens 48). So archetypes "combine universal with the individual, the general with the unique, in that they are common to all humanity, yet nevertheless manifest themselves in every human being in a way peculiar to him or to her " (50). This explains why archetypes are important in literature. They help the readers to relate certain parts of their psyche with the characters in the stories. This makes the readers more involved in the story and may even help to reveal the parts of their psyche that they weren't conciously aware of. This is because archetypes can give "rise to similar thoughts, images, mythologems, feelings, and ideas in people, irrespective of their class, creed, race, geographical location, or historical epoch" (48).

Archetypes and stereotypes are often confused to be one and the same thing. An achetype can be considered as a an already existing base model, from which similar versions are created. Whereas, a stereotype is a narrowed down concept derived from the archetype by abstracting its essence in general. Archetypes are generally more complex as opposed to the stereotypes which are usually oversimplified and often have negative connotations. Archetypes are more or less defined by their functions or their roles whereas stereotypes are often one dimensional characters that are just meant to fit the role of the archetype they 


\section{DOI: $\underline{\text { https://doi.org/10.24113/ijellh.v8i1.10413 }}$}

represent. For instance, the archetype of a helper/sidekick, is played by Robin in Batman \& Robin, by Ron and Hermionie in the Harry Potter and the Philosopher's stone, by Puss-inboots and Donkey in Shrek. However, characters like the evil step-mother in Cinderella is a stereotype of the mother archetype where the step-mother is necessarily nasty and evil.

So, if archetypes are ingrained in our unconcious since our birth, do young children also respond to these in story books and movies? Is the supporting base of archetypes enough to entice and engage a child? Children have young impressionistic minds and limited exposure to the outside world. Therefore, they may or may not be able to understand the complexities of life, form well balanced opinions and make sound judgements at a tender age. But children are curious learners and as with the adults whatever they grasp from their surroundings and experience becomes a part of their 'concious' and 'personal unconcious'. Also, given the familiar and relatable nature of the archetypes as a part of the collective unconcious, should these not present themselves as a good opportunity for the writers to exploit and readily connect with their readers? Why do some authors of children's books narrow it down and resort to stereotyping of story characters, situations and body images? The answer to this seems to be a shade of grey.

For some authors of children's books, the use stereotypes might seem desirable to a make compelling case before their juvenile readers to allow them to hate and despise the bad guy or the villain or spot a hero effortlessly by falling back on the ideas and images of the exisiting stereotypes. Thus, we find some authors taking an easy and more childish approach to hint and emphasise the role of a character or to intensify a situataion. Roald Dahl, one of the most celebrated authors of children's books also uses character stereotypes and indulges in creating negative body images in some of his famous works. In Dahl's The Twits, the physical appearance and sense of hygene of Mr Twit invites a 'disgusted reaction' from children and the sophisticated adults. Children who are taught the importance of keeping 


\section{DOI: $\underline{\text { https://doi.org/10.24113/ijellh.v8i1.10413 }}$}

themselves clean, brushing their teeth and wiping their mouths after a meal may find the actions of Mr Twit in sharp contrast to what they are generally taught at home by their parents thus signalling something wrong with him to them. Mrs Twit is also depicted as an ugly looking woman. (Twits 6-7). Similarly, in order to enhance the negative impression of the witches as villains, Dahl makes the witches look like an embodiment of evil. He gives them a 'bald head' and 'claw like fingers without fingernails'. He portrays them as children haters who find the smell of well bathed children like "dog's droppings"(Witches 22). His portyal of the witches is quite intersting and creative but making a witch ugly and hateful is quite stereotypical. He paints a rather formidible picture of Trunchbull in Matilda by stressing on her a rather odd sense of dressing and huge size. He seems to have a prejudice against fat people as both the villains in The Twits and Matilda are fat and ugly. Trunchbull is fat and formidable and stands in sharp contrast with Matilda's favourite teacher who is the 'delicate looking' and the 'oh so nice' stereotype of a school teacher. In The Witches, the emphasis is on the true ugliness of the witches hidden under their pretty disguise. The little boy's Granny is given the stereotypical image of a loving grandmother with a heavy body as depicted in the illustration in the book by Quentin Blake (Witches 23). By doing so Dahl like many other authors intends and and manages to make 'bad' not only feel but also look bad in all possible ways to the minds of the young readers by focusing on the appearance of the characters as a part of their faults.

The authors favouring the use of stereotypes seem to justify the fatal flaws of their story characters with their 'not so normal' physical appearance and dressing sense. In fairy tales, children's books and movies being fat is usually steretoyped and equated with 'being stupid and dumb' , ' pure villainy' or ' being way too jolly'. Thus raising the issue of body shaming. This cannot be good in any way. If the young readers are to equate the 'fat' with 'stupid' and 'ugly' with 'villainy' then, they are likely to do the reverse too i.e. expecting a 


\section{DOI: $\underline{\text { https://doi.org/10.24113/ijellh.v8i1.10413 }}$}

stupid person to be fat or odd and a 'not so good looking' person to be bad or nasty. It is only with more life experience and better levels of maturity that children can move past such stereotypes that may take roots in their personal unconcious affect them passively.

The authors of fairy tales and children's stories often try to impart lessons to children about how bad actions get punished. They try to create intense dislike for the villains from the very begining so that their feelings towards these villains and vamps prevent any sympathy towards the villains and vamps no matter how bad their end turns out to be. For instance, the vanishing of $\mathrm{Mr}$ and Mrs Twits by shrinking into their ownselves is a terrible way to die (Twits 86-87). But, with the backdrop of their horrible actions and the horrible appearances it looks like good justice for the monkeys and good riddance for everyone troubled by the Twits. The Twits ends with a note of jubiliation when "[T]here was nothing left in this world of Mr and Mrs Twit. And everyone, including Fred, shouted... 'Hooray!' " (87). Horrible actions do call for punishments, that is the crux of most of the children's stories. But how far is it justified to link horrible actions to repulsive appearnce? Even though Dahl uses stereotypes and tries to evoke and amplify good and bad through body images of his story characters; he wishes to use it to instruct and motivate the children to be good else they could end up becoming ugly like Mrs Twit. He explains:

If a person has ugly thoughts, it begins to show on the face. And when that person has ugly thoughts every day, every week, every year, the face gets uglier and uglier until it gets so ugly you can hardly bear to look at it. A person who has good thoughts cannot ever be ugly. You can have a wonky nose and a crooked mouth and a double chin and stick-out teeth, but if you have good thoughts they will shine out of your face like sunbeams and you will always look lovely. (Twits 7)

While this might act as a negative motivation for the children to be at their best behaviour, it also seems to reinforce a certain idea of good looks. Apparantly, a 'double chin' 


\section{DOI: $\underline{\text { https://doi.org/10.24113/ijellh.v8i1.10413 }}$}

and 'teeth sticking-out' are not 'ok' as per Dahl's beauty standards and need to be supported by good behaviour. Dahl's story books are one of the best selling children's books as he paints vivid imagery of characters and situations paired with a very compelling style of narration. However, his books do have negative stereotypes even if his intention was just to make them more abominable or pitiable in their respective roles. The reading public and audience seems to be becoming more and more sensitive to the negative effects of stereotyping certain groups, class, gender along with the the harmful nature of body shaming. Taking a clue from such an awarness, movies like Kung-fu-Panda, Megamind and Shrek along with some cartoons like Winnie the Pooh are a great success and send across the message that heros and villains come in all shapes, sizes and genders. They need'nt necessarily be very handsome/pretty or ugly. The characters in these movies are defined by their actions and are not to be judged on the basis of their appearance. This begs the question that, if children can identify and differentiate 'good' from 'bad' and differentiate between 'right' and 'wrong', then why are they been fed with negative stereotypes that create unwanted prejudices and incourage discrimination?

Why do we think that children will not be able to understand the complex human nature of the characters given their unconcious familarity with the archetypes? Movies like Kung-fu-Panda and The Shrek rely on the capturing the essence of the archetypes by focusing more on the role and function of the character. They focus on the character's growth instead of making them one dimensional by labeling them, limiting them and other developmental possibilities. Stereoypes are fairly linear characters and situations with a fairly linear trajectory of outcome which doesn't involve any other possibility than the predectible. However, movies like these have heroes with their fears, weaknesses and gullibilities along with the courage and goodness in their hearts. This makes them more relatable and not just examplary. 


\section{DOI: $\underline{\text { https://doi.org/10.24113/ijellh.v8i1.10413 }}$}

The graphic representation of the characters is also a factor that affects how we perceive an archetype or a stereotype. In The Twits, the illustrations of Mr and Mrs Twit are true to Dahl's discription in the book. The Twits look ugly and abominable in their illustrations by Quentin Blake (Twits 16-21). However, in The Witches, all of Quentin's illustrations except that of the Grand High Witch are fairly neutral i.e. neither too ugly and scary nor too good to pass off as ordinary. The Grand High Witch is sketched to look horrifying enough but not as horrid as described by Dahl. Dahl describes her as a witch with a " crumpled and wizened" face as though " it had been pickled in vinegar." He goes on to say further that, " [I]t seemed quite literally to be rotting away at the edges, and in the middle of the face, around the mouth and cheeks,...the skin all cankered and worm-eaten, as though maggots were working away there"(60).

The movies like The Shrek, Kung-fu-Panda, Megamind, Hotel Transilvaniya and many more have animations that are still pleasant to look at. For instance, the character of Shrek even though a 'hero archetype' is supposed to look ugly as the Ogres are supposedly ugly looking, violent creatures. But, the animated Shrek eventhough fat, green and very far removed from the popular idea of a good looking hero; is still acceptable due the softness in his face and our conviction about the goodness in his heart. In Megamind, the hero is a blue skined and much hated villain who turns into a hero. Similarly, Po in Kung-fu-Panda is fat but very cute and adorable. He doesn't get depressed about his shortcommings and accepts himself with great pride, as "The Fat Panda". Tai Lung in the same movie, even though a villain is not made to look ugly or hideous but his evil and anger is well projected though his expressions. This approach of mellowing down the looks which are non confirmitive to the existing beauty standards and making it more acceptable, sometimes even cute, is quite a refreshing take on the stereotypical portrayal of villains. It can have a rather positive effect on the minds of young children as they don't form notions against fat or not so good looking 


\section{DOI: $\underline{\text { https://doi.org/10.24113/ijellh.v8i1.10413 }}$}

people and escape the shameful practice of body shaming. They get an idea that beauty is skin deep and evil need'nt necessarily look evil.

When Francis Bacon in his famous essay "Of Studies" wrote that, "Some books are to be tasted, others to be swallowed, and some to be chewed on and digested " (125) and that "the studies serve for delight, for ornament, and for ability" (123); he shared some profound insights which would resonate with many generations to come after him. In the same essay he goes on to say that what and how well a person is able to make of his/her reading depends upon the reader's discretion and intentions. He suggests that one should "[R]ead not to contradict and confute; nor to believe and take for granted; nor to find talk and discourse; but to weigh and consider"(125). While the adults can be expected to exercise a sound judgement in this regard to a certain extent can we expect children to be discreet about what they read and what they take from it? More so, what they take from their loved books knowingly and unkowingly? Margaret Meek is of the opinion that children are sensitive to what is read to them in the form of stories. She explains that, "[S]tories read to them become part of their own memories. Book characters emerge in the stories of their early dramatic play as they anticipate the possibilities of their futures" (Meek 2). However, according to Gillian Avery, '[the child] has his own defence against what he doesn't like or doesn't understand in the book ... He ignores it, perhaps, or he makes something different from it ... [Children] extract what they want from a book and no more' (qtd. in Oberstein). Classic and popular works of fiction either have a soley didactic purpose hidden under the garb of fancy imagination or they are purely for entertainment with some food for thought at times. While some skilled and successful writers of children's books may have well intended reasons for their choice of character portrayal and vivid flights of fantasy, sometimes their personal narrow opinions and prejudices may affect the young minds of the children in a very negative way. Even though body shaming in the literature or the movies reflects the outlook and perspective of the author 


\section{DOI: $\underline{\text { https://doi.org/10.24113/ijellh.v8i1.10413 }}$}

or the directer, it can impact a young reader or audience by creating negativeity and fear in their minds. Sometimes body shaming can lead to lack of self confidence and low self esteem along with affects on physical health too ("This is what").

A book may have been written with entertainment as its core purpose but a child reading the book may take it more seriously than intended. Children can become prejudiced without even having had enough exposure in life to be able to reason well and form their opinions based on their own experiences. Some may do away with silly prejudices as they grow up and learn to understand the complexities of life, good and bad, right and wrong. But, some may still hold on to these prejudices unkowingly which get pushed back in their personal unconcious and lactch on to them throughout their lives. Thus, creating a narrow and polarised view of the world. According to Karin Lesnik-Oberstein, children's literature "means in its most fundamental sense to every critic who uses the term: books which are good for children, most particularly good in terms of emotional and moral values" (Oberstein 17). Also, Michele Landsberg believes that good books can do so much for children. At their best, they expand horizons and instil in children a sense of the wonderful complexity of life...No other pastime available to children is so conducive to empathy and the enlarement of human sympathies. No other pleasure can so richly furnish a child's mind with symbols, patterns, depths, and possibilities of civilisation. (qtd. in Oberstein) Thus, authors of children's books need to be careful with their stories, character portrayal and the messages that they send across both intensionally and unintensionally. 


\section{DOI: $\underline{\text { https://doi.org/10.24113/ijellh.v8i1.10413 }}$}

\section{Works Cited}

Bacon, Francis. The Essays of Francis Bacon. Amazon Kindle ed., n.p, n.d.

Batman \& Robin. Directed by Joel Schumacher, Warner Bros. Pictures, 1997.

Cinderella. Directed by Kenneth Branagh, Walt Disney Studios, 2015.

Dahl, Roald. Matilda. Illus. Quentin Blake. Puffin Books, 2016.

---. The Twits. Illus. Quentin Blake. Puffin Books, 2016.

---. The Witches. Illus. Quentin Blake. Puffin Books, 2016.

Harry Potter and the Philosopher's Stone. Directed by Chris Columbus, Warner Bros. Pictures, 2001.

Hotel Transilvania. Directed by Genndy Tartakovsky, Sony Pictures Realising, 2012.

Kung Fu Panda. Directed by Mark Osborne and John Stevenson, Paramount Pictures, 2008.

Meek, Margeret. Introduction. International Companion Encyclopedia of Children's

Literature, edited by Peter Hunt, Routledge, 2006, pp. 1-11.

Megamind. Directed by Tom McGrath, Paramount Pictures, 2010.

Oberstein, Karin Lesnik. "Defining Children's Literature and Childhood." International Companion Encyclopedia of Children's Literature, edited by Peter Hunt, Routledge, 2006, pp. 17-29.

Shrek. Directed by Andrew Adamson and Vicky Jenson, DreamWorks Pictures, 2001.

Stevens, Anthony. Jung: A very Short Introduction. Oxford UP, 2001.

"This is what body shaming is doing to your mental health: Why you should refrain from body shaming." Timesnownews, 15 December 2018, www.timesnownews.com/health/article/what-body-shaming-is-doing-to-your-mentalhealth-refrain-from-body-shaming/331436.

Winnie the Pooh. Directed by Stephen J. Anderson and Don Hall, Walt Disney Studios, 2011. 